\title{
Air Quality Over Major Cities of Saudi Arabia During Hajj Periods of 2019 and 2020
}

\author{
Ashraf Farahat ${ }^{1}$ (D) Akshansha Chauhan ${ }^{2} \cdot$ Mohammed Al Otaibi $^{3} \cdot$ Ramesh P. Singh $^{4}$
}

Received: 25 October 2020 / Accepted: 13 January 2021 / Published online: 2 February 2021

(c) The Author(s) 2021

\begin{abstract}
Mecca and Madinah are two holy cities where millions of people in general, visit throughout the years, during Hajj (Muslim's pilgrimage) time number of people visit these holy cities from different parts of the world is very high. However, the Government of Saudi Arabia only allowed 1000 pilgrims during the 2020 Hajj especially when the world is suffering from COVID-19. In the present paper, a detailed analysis of air quality parameters available from ground measurements have been carried over major cities of Saudi Arabia, Mecca, Madinah, and Jeddah from June to September 2019 and 2020. At Mecca and Jeddah, $\mathrm{PM}_{10}, \mathrm{NO}_{2}$ and $\mathrm{CO}$ concentrations are found to be higher in comparison to stations located close to Madinah. In addition, meteorological parameters, temperature, relative humidity, and wind directions are also analysed to understand changes associated with the meteorological parameters. Our detailed analysis shows a reduction in concentrations of pollutants during the 2020 Hajj, when the lockdown was observed in Saudi Arabia due to COVID-19. During June-August 2020 lockdown period, no major changes in $\mathrm{PM}_{10}$ concentration was observed since there were frequent dust events were observed. In contrast, our results show $44 \%$ reduction in $\mathrm{NO}_{2}$ (8.77 ppbv in 2019 to 4.97 ppbv in 2020) and 16\% reduction in $\mathrm{CO}\left(0.85 \mathrm{ppm}\right.$ in 2019 to $0.72 \mathrm{ppm}$ in 2020) concentrations during COVID-19 restrictions. The concentrations of $\mathrm{NO}_{2}$ and $\mathrm{CO}$ do not cause any issue for the air quality as $\mathrm{NO}_{2}$ and $\mathrm{CO}$ Indices lie within the green band (Air quality index 0-50). In Mecca, Madinah and Jeddah, the air quality is generally affected during Hajj, but during 2020, the concentration of particulate matter was influenced by local weather conditions.
\end{abstract}

Keywords Air quality · Hajj 2020 - COVID-19 · Lockdown · Saudi Arabia

\section{Introduction}

Ashraf Farahat

ashraf.farahat@kfupm.edu.sa

1 Department of Physics, College of General Studies, King Fahd University of Petroleum, and Minerals, Dhahran 31261, Saudi Arabia

2 Center for Space and Remote Sensing Research, National Central University, Taoyuan, Taiwan

3 Health, Safety, Security and Environment Excellence Section, Industrial Security and Responsibility Care Department, Sahara International Petrochemical Company, SIPCHEM, Jubail Industrial City 31961, Saudi Arabia

4 School of Life and Environmental Sciences, Schmid College of Science and Technology, Chapman University, Orange, CA 92866, USA
Mecca and Madinah are the holy cities located in the western parts of the Kingdom of Saudi Arabia where millions of pilgrimage visits during Hajj (Muslim's pilgrimage) time. Over the years, the number of pilgrimages have increased up to three million (Ascoura 2013; Mirza 2020). The major parts of Saudi Arabia are occupied by desert, during the summer season with strong winds, desert soils uplifted in the atmosphere, cause heavy aerosols loading (Alam et al. 2014; Farahat et al. 2015; PME 2012). The desert areas of Saudi Arabia suffer from higher concentrations of particulate matter due to dust storms and construction activities (Alam et al. 2014; Farahat et al. 2016; Farahat 2019; Khodeir et al. 2012), with higher Ozone concentration and photochemical smog depending on the meteorological conditions (Lelieveld et al. 2009). Large number of vehicles on the road cause greenhouse gas emissions and volatile organic compounds (VOCs) 
(Rahman et al. 2017). Lim et al. (2018) suggested longrange transport of residual oil-burning aerosols that affect the air quality in Mecca even most of the oil deposits are located in the north-eastern parts of Saudi Arabia.

The COVID-19 affected many parts of the world, social distancing was observed, and work restrictions were imposed to mitigate the spread of the COVID-19. Such restrictions helped to improve the air quality of major cities of the world due to reductions in traffic and closure of industries (Chauhan and Singh 2020a,b; Connerton et al. 2020; Kumar et al. 2020; Singh and Chauhan 2020). The major anthropogenic activities related to the 2020 Hajj were also minimized that lead to reductions in the major pollutants in Mecca, Madinah, and Jeddah. In the present paper, we have carried out the analysis of air quality parameters (particulate matter and trace gases) in three major cities during 2019 and 2020 Hajj. Our results show pronounced changes in particulate matter, $\mathrm{NO}_{2}$ and $\mathrm{CO}$ concentrations.

\subsection{Major Cities of Western Saudi Arabia}

Mecca, Madinah, and Jeddah are three major cities located at the western province of Saudi Arabia. Mecca is the holy city of the Islamic world, located in western Saudi Arabia $\left(21.42^{\circ} \mathrm{N}, 39.82^{\circ} \mathrm{E}\right.$; population 1.96 million) inland from the Red Sea coast (United Nations 2018). The elevation of the city is $277 \mathrm{~m}$ above the mean sea level (amsl) and the city is surrounded by Sarawat Mountains from three sides (Fig. 1). Madinah $\left(24.47^{\circ} \mathrm{N}, 39.60^{\circ} \mathrm{E}\right.$; population 1.3 million) in the northwest of Mecca and is the second holy city of the Islamic world. Jeddah $\left(21.54^{\circ} \mathrm{N}, 39.17^{\circ} \mathrm{E}\right.$; population 3.2 million) is the second-largest populated cities after the capital city Riyadh. Mecca, Madinah, and Jeddah are located in the semi-arid/arid regions of Saudi Arabia with an average rainfall less than $130 \mathrm{~mm}$, mainly during the winter season (Farahat 2016). During summer, the average maximum temperature often exceeds $38^{\circ} \mathrm{C}$ with lower precipitation (less than $10 \mathrm{~mm}$ ) (Hasanean and Almazroui 2015; Howarth

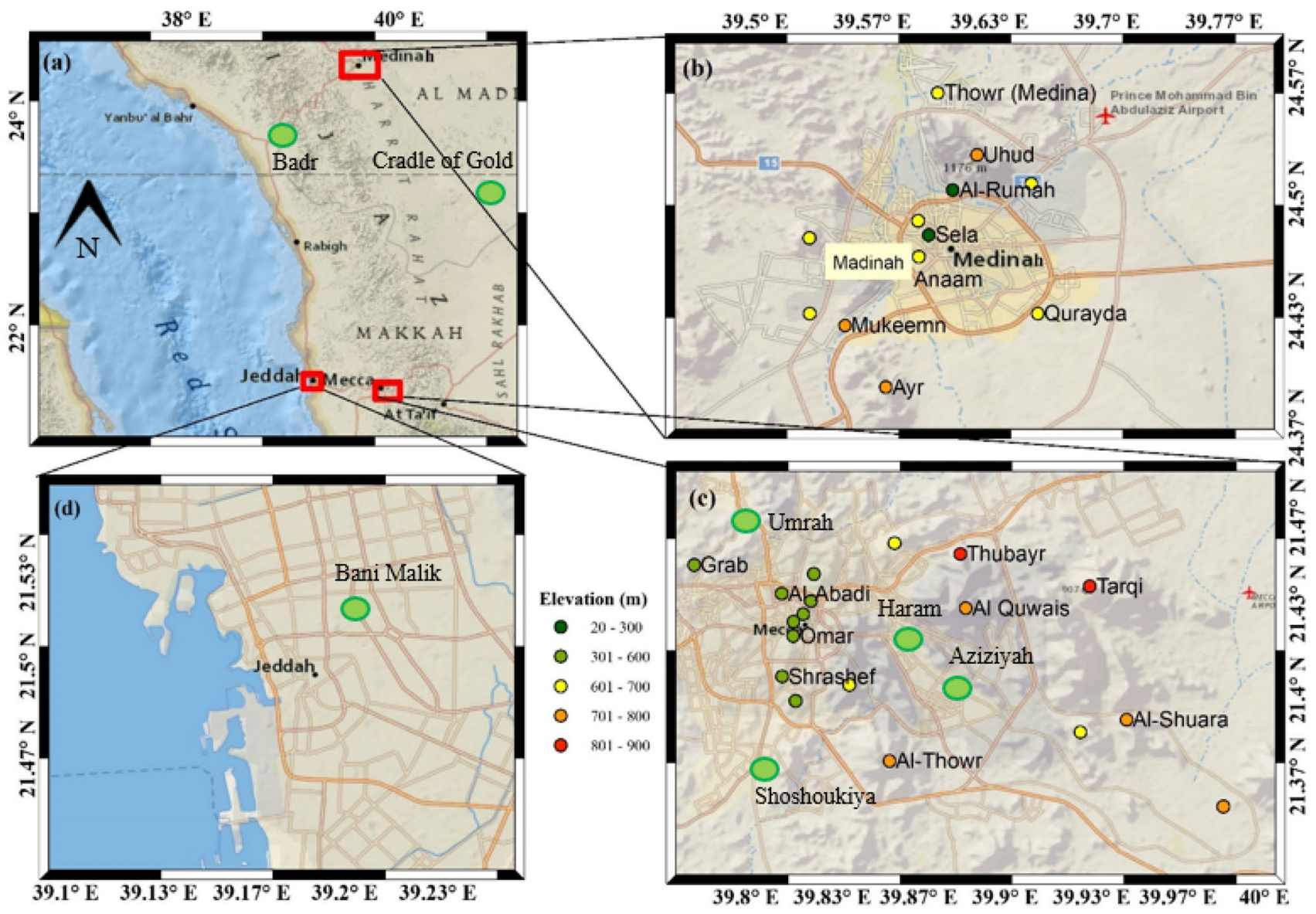

Fig. 1 a The location of three city Mecca, Madinah, and Jeddah in Saudi Arabia (base layer source: National Geography). The colour circle shows the location of mountains peaks around, b Madinah, c
Mecca and $\mathbf{d}$ Jeddah. The colour of each location depends on the elevation of the mountain peak. Location of ground station (shown by Green circles) for the measurement of various air quality parameters 
et al. 2020; Nayebare et al. 2018). Anthropogenic and natural emissions from dust storms, large construction activties, traffic, petrochemical, and cement industries affect particulate matter loading in the atmosphere (Al-Jeelani 2009; Othman et al. 2010; Seroji 2011; Mohammed et al. 2015, 2016; Munir et al. 2016; Lim et al. 2018; Nayebare et al. 2018; Al Otaibi et al. 2019) .

During 2019 Hajj time, around 2.5 million pilgrims gathered in Mecca (Mirza 2020). Each year, Hajj starts in Dhu al-Hijjah, in the last month of the Islamic Calendar, for 5-days duration. Pilgrims arrive to the city of Mecca about 5 days before the Hajj starts and leave 4-5 days after the last day of Hajj.

During Hajj, pilgrims visit from every country in the world, but the number of visitors within Saudi Arabia are the highest. As there is no airport in Mecca, many international pilgrims travel by air to King Abdulaziz International Airport (JED) in the city of Jeddah (about $85 \mathrm{~km}$ from Mecca) and domestic pilgrims travel to Mecca by local transport buses, cars, and taxis. In 2019, more than 18,000 buses were used to transport the pilgrims to Mecca (Vincent 2019). Some pilgrims come to the Prince Mohammad Bin AbdulAziz International Airport (MED) in the city of Madinah (about $450 \mathrm{~km}$ from Mecca) and Taif International Airport (TIF) (about $86 \mathrm{~km}$ ) and use local transport to reach at the Hajj location.

The number of visitors during Hajj time is growing every year; as a result, human activities and traffic have also increased, affecting air quality (Siddique 2016; Simpson et al. 2014). Moreover, Mecca and Madinah are expanding at a rapid rate and large scale of construction and demolition activties, which is also affecting the air quality of the two holy cities (Abdel Hameed et al. 2016; Al-Jeelani 2009; Mohammed et al. 2015; Munir et al. 2016; Othman et al. 2010; Seroji 2011). The city of Jeddah has poor air quality mostly affected by desert dust, vehicular emission, and other anthropogenic activities (Barletta et al. 2017; Hussain et al. 2014; Mashat et al. 2018; Munir et al. 2013, 2016; Nayebare et al. 2018; Taylan 2013).

\subsection{COVID-19 and Hajj 2020}

In 2020, during Cthe OVID-19 pandemic, the Government of Saudi Arabia imposed a lockdown to stop the spread of COVID-19, however, more than 2, 87,262 people suffered in Saudi Arabia and more than 3000 people died until 31 August 2020 (Corona Tracker 2020). Hajj was also affected by the COVID-19, only the Government restricted 1000 pilgrims (SPA 2020) to Mecca (Fig. 2). Further, all pilgrims were restricted to stay in Mecca only and no one could travel to Madinah. Fourteen days of quarantine were imposed on pilgrims before and after the Hajj. Regular health checkups, social distancing and electronic monitoring of everyone were mandatory during the 2020 Hajj period (Ministry of Hajj and Umrah 2020).

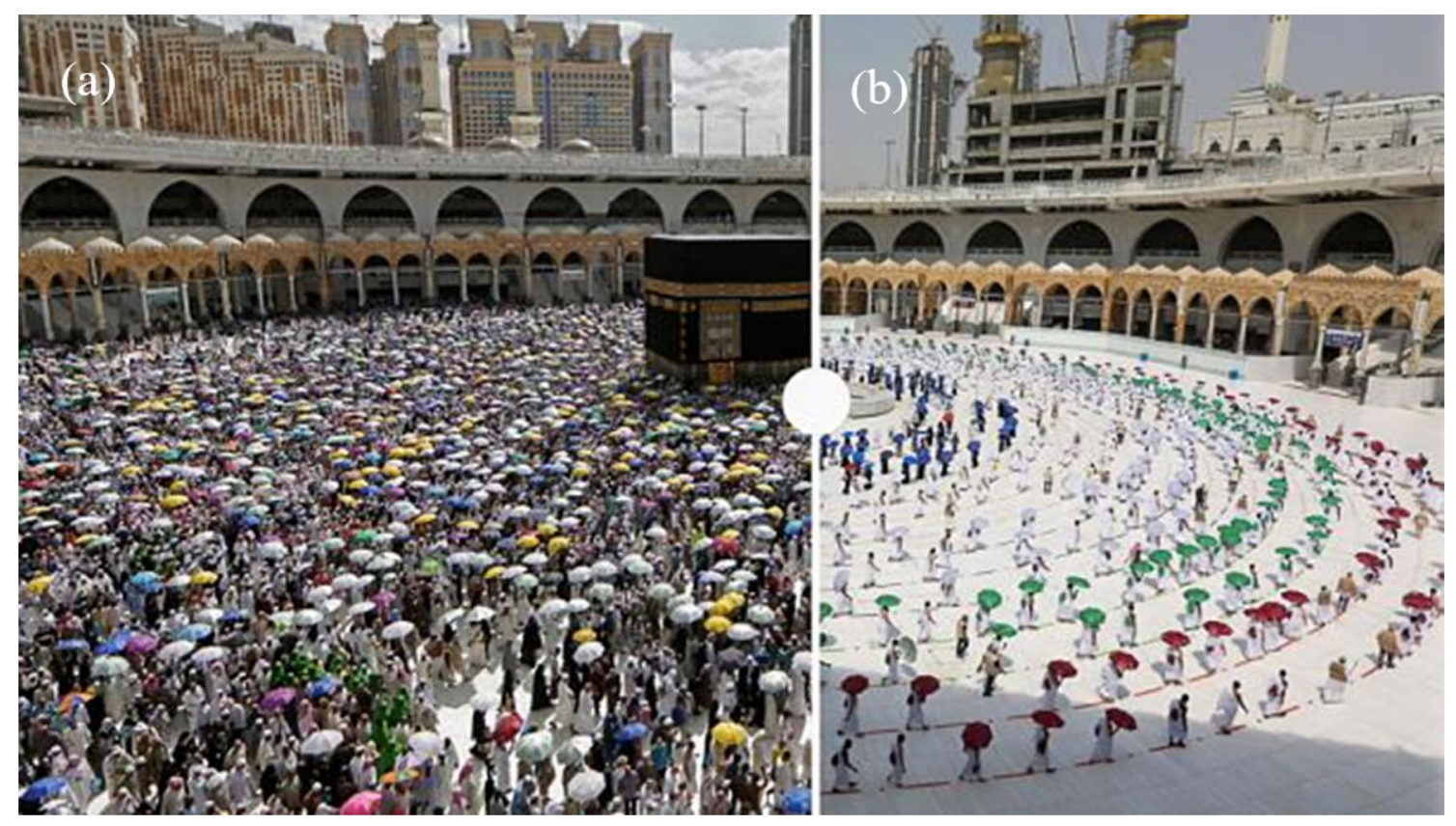

Fig. 2 Pilgrims for Hajj in Mecca in a 2019 and b 2020 (Source: Saudi Ministry of Media/AFP and Euro News 2020) 


\section{Data Used and Methodology}

The Hajj was organised during 9-14 August 2019 and 28 July-2 August 2020, respectively. We have considered three periods, before, during, and after for 2019 and 2020 Hajj periods. For each year, we have considered 10 days before and 10 days after the date of starting and end of Hajj. The air quality parameters $\left(\mathrm{PM}_{10}, \mathrm{NO}_{2}\right.$ and $\left.\mathrm{CO}\right)$ from ground stations located in Mecca, Madinah, and Jeddah are considered (Fig. 1).

\subsection{Air Quality Parameters}

The air quality parameters for Mecca, Madinah, and Jeddah are taken from the World Air Quality Index Project (WAQIP 2020). Using standard monitoring equipment, the concentration of various pollutants is observed at all locations of the World Air Quality Index Project by each countries' respective Environmental Protection Agency (EPA). In Saudi Arabia, the concentration of the various pollutants is provided by Saudi Arabia General Authority for Meteorology and Environmental Protection (MEWA 2020). The index of each parameter is calculated by WAQIP using the US Environmental Protection Agency formula (USEPA 2020). The raw data of $\mathrm{PM}_{10}, \mathrm{NO}_{2}$, and $\mathrm{CO}$ is not available through the website, however, the index of $\mathrm{PM}_{10}, \mathrm{NO}_{2}$, and $\mathrm{CO}$ are available through the WAQIP server. The list of all World Air Quality Index Project (WAQIP) stations are available from (WAQIP 2020).

We have considered air quality data for the periods July 2019-August 2020 from 7 ground stations (coordinates of these stations are given in Table 1), stations 1-4 are located in Mecca city, station 5 is located in Jeddah and Stations 6 and 7 are nearby to the Madinah (Fig. 1). The distance of station 6 is $70 \mathrm{~km}$ and station 7 is $100 \mathrm{~km}$ from the Madinah city center, no station is located in Madinah city.

In our analysis, we have also calculated the average concentration of each parameter using USEPA procedures and the details are given in USEPA technical report (USEPA 2020).

Table 1 Name of stations and coordinates

\begin{tabular}{lllll}
\hline SI. no. & City & Station name & Latitude $\left({ }^{\circ} \mathrm{N}\right)$ & Longitude $\left({ }^{\circ} \mathrm{E}\right)$ \\
\hline 1 & Mecca & Aziziyah & 21.40 & 39.88 \\
2 & Mecca & Umrah & 21.51 & 39.79 \\
3 & Mecca & Al Shoqiyah & 21.37 & 39.81 \\
4 & Mecca & Haram & 21.42 & 39.83 \\
5 & Jeddah & Bani Malik & 21.52 & 39.20 \\
6 & Madinah & Badr & 23.78 & 38.80 \\
7 & Madinah & Cradle of Gold & 23.50 & 40.89 \\
\hline
\end{tabular}

\subsection{Meteorological Parameters}

We have carried out the analysis of meteorological parameters (air temperature, air pressure, relative humidity, wind velocity, and wind direction) for the periods 2019 and 2020 using the data provided by Reliable Prognosis. The website has been designed and supported by Raspisaniye Pogodi Ltd., St. Petersburg, Russia, since 2004. This website provides actual and forecast data of weather using various ground observations. The forecasts are prepared by the Met Office, the United Kingdom, and available through the website under the contract between the Met Office and Raspisaniye Pogodi Ltd. Information on the actual weather comes from the server of international data exchange, NOAA, United States, in SYNOP and METAR formats. All the data are fully quality controlled and are freely available.

\section{Result and Discussion}

\subsection{Meteorology of Mecca (Jeddah) and Madinah}

In Mecca and Jeddah, dominant wind is northerly and westerly during July and August 2019, with a small component of southerly wind during August 2019 (Fig. 3). In June 2020, the dominant wind is north-westerly to westerly. During July 2020 , wind is westerly with a southerly component and in August 2020, the wind pattern is north-westerly to westerly, similar wind pattern was observed in these months during 2019 (Fig. 3).

In Madinah, dominant wind is south-westerly to northerly during June, July and August 2019 and 2020, almost similar for these months in the year 2019 without major changes in wind direction.

We have also analysed air temperature, relative humidity, and air pressure at Mecca, Madinah, and Jeddah. The meteorological parameters available of Mecca and Jeddah are the same as assimilated data of various resources provided by Reliable Prognosis, so we have shown only for Mecca.

In Mecca, the average temperature increases during June-August (Fig. 4); the mean temperature during July and August 2019 was $34^{\circ} \mathrm{C}$. During 2020, the average temperature varies, $32{ }^{\circ} \mathrm{C}$ during June, $33.5^{\circ} \mathrm{C}$ during July and $34^{\circ} \mathrm{C}$ during August, the air temperature in both years was similar during Hajj periods. A reduction in $0.17 \%$ is observed in air pressure and $1.80 \%$ rise in average relative humidity during July and August 2020 compared to 2019 in Mecca. In Madinah, fall of about $1.05 \%$ in air temperature and $0.18 \%$ in air pressure was observed, whereas, $40 \%$ rise in relative humidity was observed in Madinah during 2020. A sudden rise in relative humidity was observed during the 2020 Hajj in Madinah and a similar rise was observed during the 2019 Hajj. 


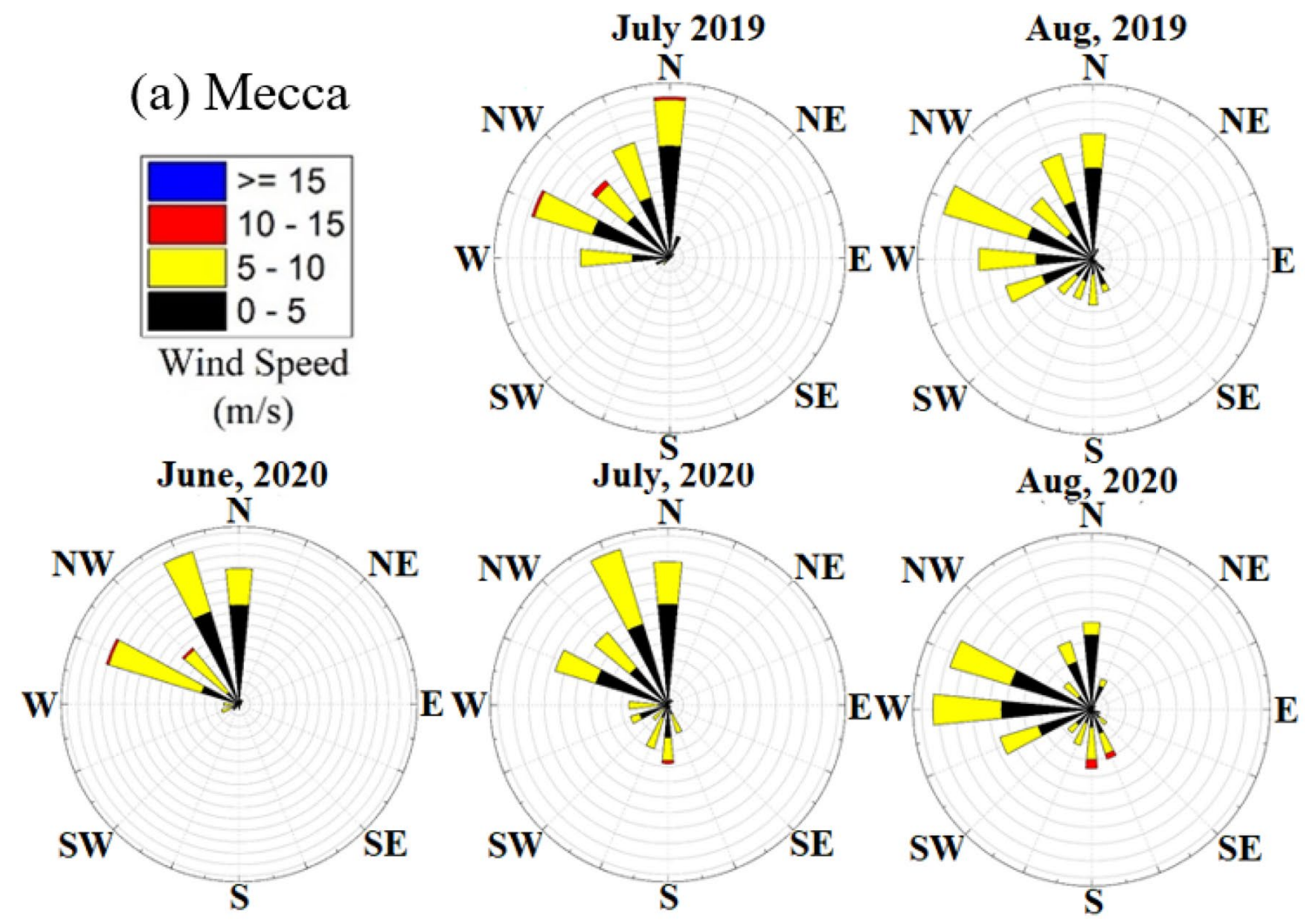

(b) Madinah
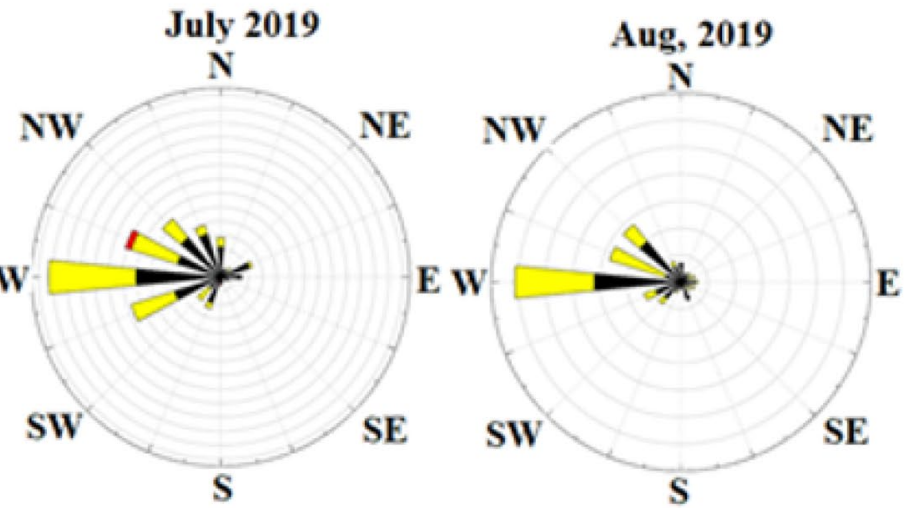

June, 2020

Julv, 2020

Aug, 2020
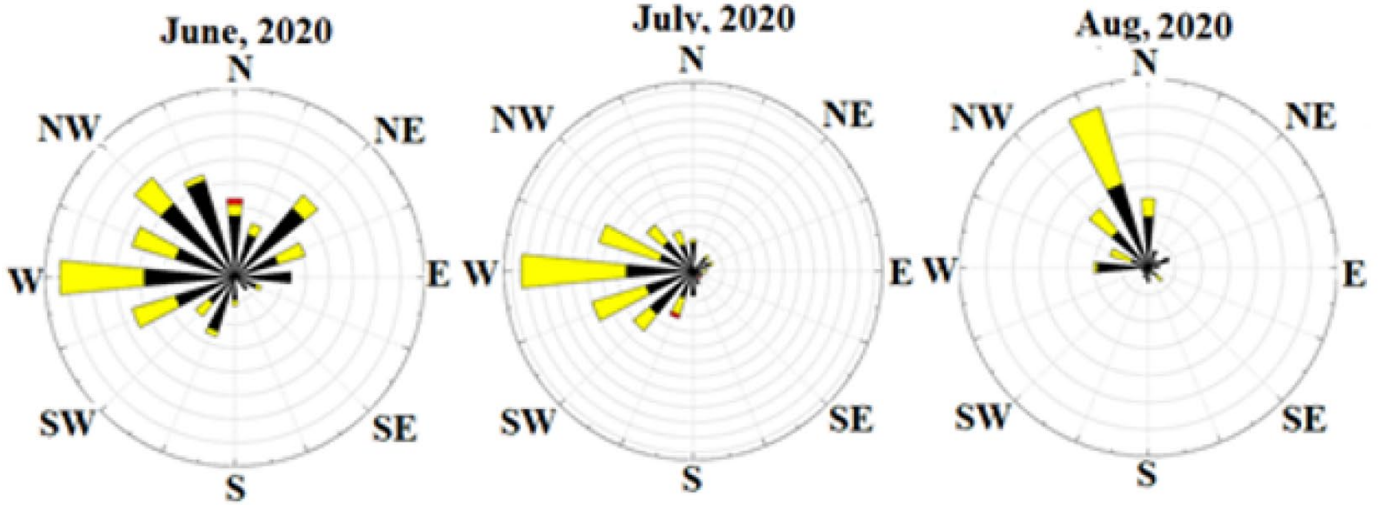

Fig. 3 The wind rose diagrams for a Mecca and $\mathbf{b}$ Madinah during June, July and August 2019 and 2020. The dominant wind at Mecca is north-west and westerly winds during July 2019 and 2020. At Mad- inah, dominant westerly winds were observed during 2019 and 2020. The wind direction at Jeddah and Mecca are observed to be similar (Weather in the World 2020) 


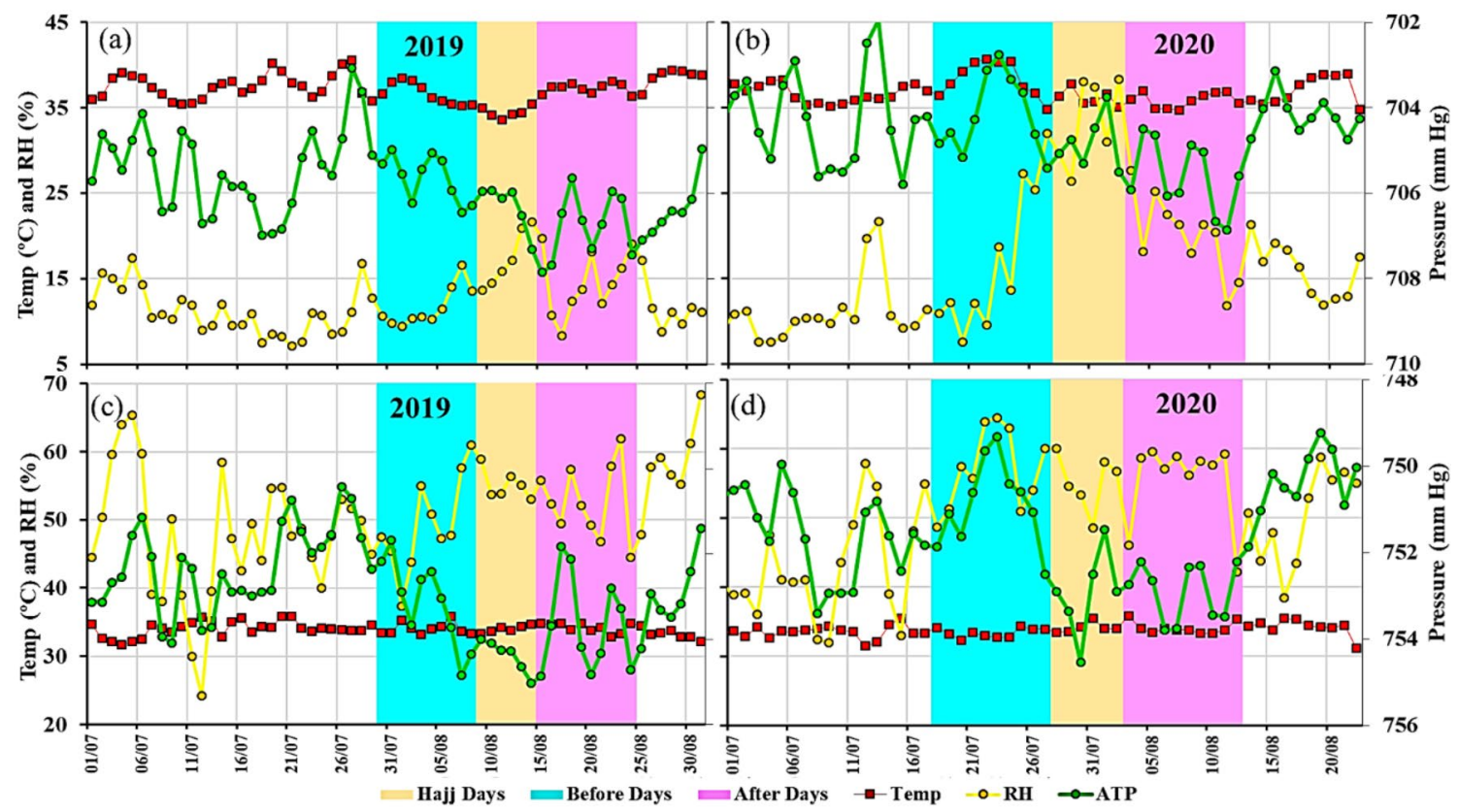

Fig. 4 Temporal variations of air temperature $\left({ }^{\circ} \mathrm{C}\right)$, relative humidity (\%) and air pressure ( $\mathrm{mm} \mathrm{Hg}$ ) at a Madinah during 2019; b Madinah during 2020; c Mecca during 2019 and d Mecca during 2020

\subsection{Variations in Particulate Matter concentrations}

Figure 5 and Table 2 show the temporal variations of $\mathrm{PM}_{10}$ index at Mecca, Jeddah, and Madinah.

In Mecca (Fig. 5a), during 2019, we found that from 30 July-08 August (before Hajj), the average $\mathrm{PM}_{10}$ index is 58.81 (equivalent to $\mathrm{PM}_{10}$ concentration $70.77 \mu \mathrm{g} / \mathrm{m}^{3}$ ). From 9 to 14 August 2019 (during Hajj), the average $\mathrm{PM}_{10}$ index was 25.42 (equivalent to $\mathrm{PM}_{10}$ concentration $27.45 \mu \mathrm{g}$ / $\mathrm{m}^{3}$ ). From 15 to 24 August 2019 (after Hajj), the average $\mathrm{PM}_{10}$ index was 27.45 (equivalent to $\mathrm{PM}_{10}$ concentration $29.65 \mu \mathrm{g} / \mathrm{m}^{3}$ ). During 2020, we observed that during 18-27 July (before Hajj) the average $\mathrm{PM}_{10}$ index was 30.11 (equivalent to $\mathrm{PM}_{10}$ concentration $32.52 \mu \mathrm{g} / \mathrm{m}^{3}$ ). During 28 July-02 August (during 2020 Hajj), the average $\mathrm{PM}_{10}$ index was 32.08 (equivalent to $\mathrm{PM}_{10}$ concentration $34.65 \mu \mathrm{g} / \mathrm{m}^{3}$ ). During 3-12 August 2020 (after Hajj), the average $\mathrm{PM}_{10}$ index was 42.74 (equivalent to PM10 concentration $46.16 \mu \mathrm{g} / \mathrm{m}^{3}$ ).

Figure 5a shows that there was an increase in $\mathrm{PM}_{10}$ concentration before 2019 and 2020 Hajj. This increase was attributed to large anthropogenic emissions associated with traffic and human activities especially when pilgrims moved to Mecca. In 2020, $\mathrm{PM}_{10}$ concentration decreased by about $57.7 \%$ compared to 2019 before the Hajj period. PM $_{10}$ concentration during the 2019 and 2020 Hajj was very comparable. This was due to the pilgrims stayed inside the holy sites in Mecca and transported by buses and trains, where small and private vehicles were restricted. This clearly shows that $\mathrm{PM}_{10}$ loading was mostly affected by a large number of vehicles used to transport pilgrims to Mecca and not necessarily affected by the number of pilgrims visiting the city. It was also interesting to observe that after Hajj, $\mathrm{PM}_{10}$ concentration increased by only $11.1 \%$ and $31.1 \%$ during 2019 and 2020 Hajj respectively. This was due to a number of pilgrims who stayed for some time in Mecca and also some of them visited other surrounding cities, like Madinah after Hajj. But prior to the Hajj periods, especially one or two days, the traffic was crowded which was seen from the poor air quality, $\mathrm{PM}_{10}$ concentration prior and after the $2020 \mathrm{Hajj}$ was slightly higher compared to 2019 , but this was attributed to strong wind and natural aerosol loading in the atmosphere (Fig. 3).

In Jeddah (Fig. 5b, Table 2), during 2020 Hajj, the average $\mathrm{PM}_{10}$ index was 11.25 (equivalent to $12.15 \mu \mathrm{g} / \mathrm{m}^{3}$ ) after Hajj while data is missing before and during the 2019 Hajj. In 2020, the average $\mathrm{PM}_{10}$ index was 14.00, 23.00 and 30.80 (equivalent to $15.12,25.06$ and $33.26 \mu \mathrm{g} / \mathrm{m}^{3}$ ), respectively, before, during and after Hajj. These are higher values compared with the average monthly values during 2019 . Although the main airport (King Abdulaziz International) is located in Jeddah city where most of the pilgrims commute to Mecca and Hajj activities did not affect air quality in Jeddah during 2020. As data is missing for 2019, it was difficult to conclude if Jeddah had similar PM $_{10}$ variations during the 2019 Hajj.

Near Madinah, in Cradle of Gold station, in 2019, the average $\mathrm{PM}_{10}$ index is $19.56,10.17$, and 15.80 (equivalent to $21.12,10.98$ and $17.06 \mu \mathrm{g} / \mathrm{m}^{3}$ ) before, during, and after 


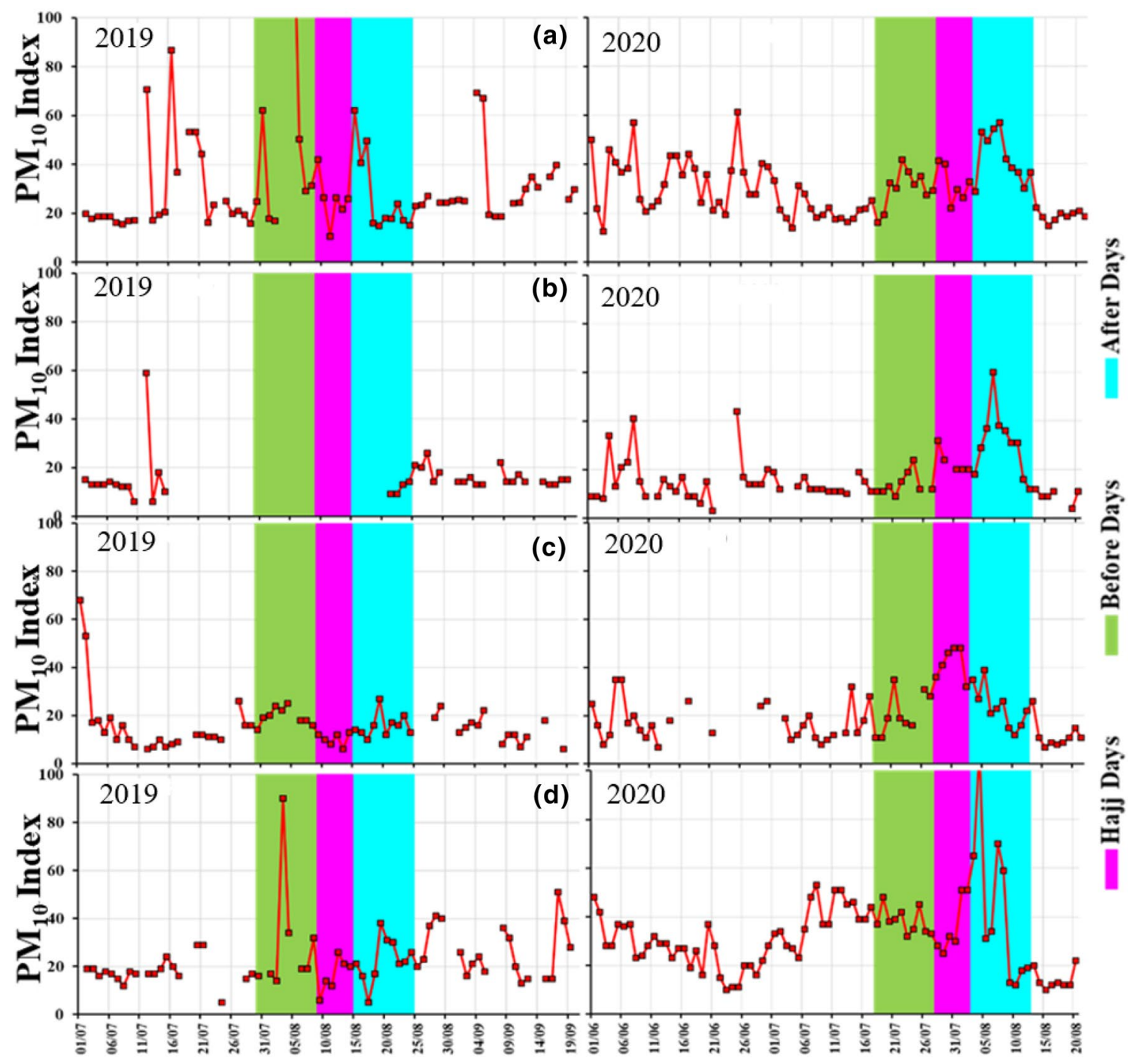

Fig. 5 Temporal Variations of $\mathrm{PM}_{10}$ index over a Mecca, b Jeddah, c Cradle of Gold Station, Madinah and d Badr Station, Madinah during 2019 and 2020, data is available for July 2019

Hajj, respectively. In 2020, the average $\mathrm{PM}_{10}$ index is 20.78 , 41.83 and 23.60 (equivalent to $22.44,45.18$ and $25.49 \mu \mathrm{g} /$ $\mathrm{m}^{3}$ ) before, during and after Hajj, respectively (Fig. 5c). These are higher values compared with the average monthly values during 2019. At Badr station (Fig. 5d), in 2019, the average $\mathrm{PM}_{10}$ index was $30.13,16.50$ and 22.70 (equivalent to $32.54,17.82$ and $24.52 \mu \mathrm{g} / \mathrm{m}^{3}$ ) before, during, and after Hajj, respectively. In 2020, the average $\mathrm{PM}_{10}$ index was $38.30,36.17$ and 43.00 (equivalent to $41.36,39.06$ and $46.44 \mu \mathrm{g} / \mathrm{m}^{3}$ ) before, during and after Hajj, respectively (Fig. 5d).

Figure 6 shows the monthly average variations of $\mathrm{PM}_{10}$ index at Mecca, Jeddah, COD (Cradle of Gold) and Badr stations near Madinah. During 2019, we found an average $\mathrm{PM}_{10}$ index in Mecca was 59\% higher compared to Jeddah, COD, and Badr, whereas, in 2020, $\mathrm{PM}_{10}$ index was found to be lower compared to COD and Badr. In 2020, pilgrims were restricted to visit Madinah, thus the observed $\mathrm{PM}_{10}$ concertation observed at COD and Badr stations were due to natural and local anthropogenic emissions.

We also observed a dust storm in Mecca and surrounding regions during 5-8 August 2019 in the Arabian Peninsula that enhanced the $\mathrm{PM}_{10}$ index more than 150 (equivalent to $\mathrm{PM}_{10}$ concentration $251 \mu \mathrm{g} / \mathrm{m}^{3}$ ) in Mecca (Fig. 7a). In 2020, we found a sudden rise in $\mathrm{PM}_{10}$ Index (concentration) during 3-12 August at Mecca, Badr and Jeddah. Further analysis shows that the region is continuously affected by the dust events (Fig. 7b), as a result the $\mathrm{PM}_{10}$ index enhanced and its affect is seen through the poor visibility. This indicates that dust storms and other meteorological conditions in Mecca and in Jeddah and Madinah (Badr and COD stations) 
Table 2 Average concentration of $\mathrm{PM}_{10}, \mathrm{NO}_{2}$ and $\mathrm{CO}$ at Mecca, Jeddah, $\mathrm{COD}$ and Badr stations

\begin{tabular}{|c|c|c|c|c|c|c|c|c|}
\hline & \multirow{2}{*}{\multicolumn{2}{|c|}{ Mecca }} & \multirow{2}{*}{\multicolumn{2}{|c|}{ Jeddah }} & \multicolumn{4}{|c|}{ Near Madinah } \\
\hline & & & & & \multicolumn{2}{|c|}{ Cradle of Gold } & \multirow[b]{2}{*}{2019} & Badr \\
\hline & 2019 & 2020 & 2019 & 2020 & 2019 & 2020 & & 2020 \\
\hline \multicolumn{9}{|c|}{$\mathrm{PM}_{10}\left(\mu \mathrm{g} / \mathrm{m}^{3}\right)$} \\
\hline Before & 70.77 & 32.52 & No data & 15.12 & 21.12 & 22.44 & 32.54 & 41.36 \\
\hline During & 27.45 & 34.65 & No data & 25.06 & 10.98 & 45.18 & 17.82 & 39.06 \\
\hline After & 29.65 & 46.16 & 12.15 & 33.26 & 17.06 & 25.49 & 24.52 & 46.44 \\
\hline \multicolumn{9}{|c|}{$\mathrm{NO}_{2}$ (ppbv) } \\
\hline Before & 9.60 & 5.30 & No data & 5.08 & 4.08 & 1.51 & No data available & 2.92 \\
\hline During & 9.95 & 4.50 & No data & 2.16 & 4.86 & 1.44 & 7.56 & 1.98 \\
\hline After & 9.86 & 3.48 & 11.23 & 2.38 & 4.86 & 1.08 & 3.24 & 3.02 \\
\hline \multicolumn{9}{|c|}{$\mathrm{CO}(\mathrm{ppm})$} \\
\hline Before & 0.83 & 0.71 & No data & 0.64 & 0.87 & 0.57 & 1.15 & 0.79 \\
\hline During & 1.28 & 0.81 & No data & 0.48 & 0.92 & 0.81 & 0.79 & 0.70 \\
\hline After & 1.08 & 0.75 & 2.06 & 0.86 & 0.92 & 0.90 & 0.99 & 0.66 \\
\hline
\end{tabular}

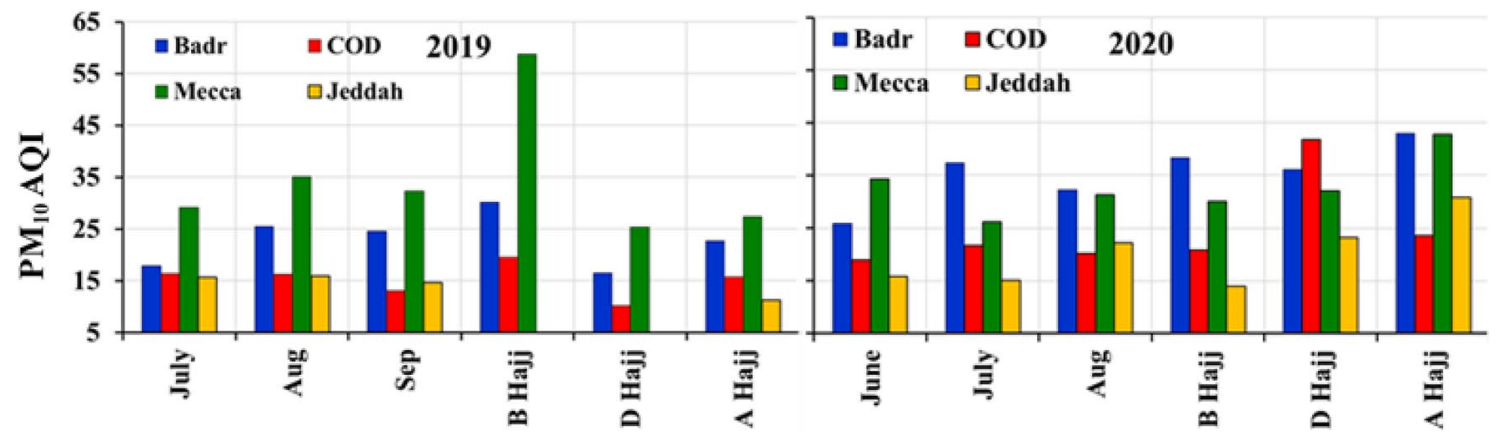

Fig. 6 Average PM $_{10}$ index over Jeddah, Badr Station Madinah, COD (cradle of gold) Station, Madinah, and Mecca during 2019 and 2020. B Hajj (before Hajj); D Hajj (during Hajj) and A Hajj (after Hajj)

are contributing to variations of $\mathrm{PM}_{10}$ concentration over the three cities.

\subsection{Changes in $\mathrm{NO}_{2}$ Concentrations}

Vehicular emissions are considered one the major sources of surface $\mathrm{NO}_{2}$ in Saudi Arabia (Al Otaibi 2019, Farahat 2016). The temporal variations of $\mathrm{NO}_{2}$ are displayed over Mecca, Jeddah, COD and Badr stations near Madinah (Fig. 8, Table 2).

In Mecca, in 2019, the average $\mathrm{NO}_{2}$ Index is $8.89,9.21$, and 9.13 (equivalent to $9.60,9.95$ and $9.86 \mathrm{ppbv}$ (parts per billion) concentration) before, during and after Hajj, respectively (Fig. 8a, Table 2). In 2020, the average $\mathrm{NO}_{2}$ Index is $4.91,4.17$ and 3.23 (equivalent to 5.30, 4.50 and $3.48 \mathrm{ppbv}$ ) before, during, and after Hajj, respectively. A reduction of $44 \%$ was found in the monthly mean $\mathrm{NO}_{2}$ in 2020 . Interestingly, in 2019, a sharp increase in $\mathrm{NO}_{2}$ Index is observed before and after Hajj. This was clearly observed by the two peaks in $\mathrm{NO}_{2}$ index around 4 and 31 August (Fig. 8a). Similar increasing trend of $\mathrm{NO}_{2}$ is observed in 2020 but with low values compared to 2019. The increase is observed around 15 August, about 2 days after Hajj officially ended in 2020, which clearly shows the effect of traffic in increasing $\mathrm{NO}_{2}$ during 2019 Hajj compared to 2020 Hajj. We found an average reduction of $44 \%$ in the months of July and August 2020 and a reduction of more than 55\% during the whole 2020 Hajj season in Mecca compared to 2019.

In Jeddah, in 2019, the average $\mathrm{NO}_{2}$ Index was 10.40 (equivalent to $11.23 \mathrm{ppbv}$ ) after $\mathrm{Hajj}$, the station data of before and during Hajj in 2019 at Jeddah was not available. Enhancement in $\mathrm{NO}_{2}$ concentration was observed during 20-25 August 2019. In 2020, the average $\mathrm{NO}_{2}$ Index is 4.70, 2.0 and 2.20 (equivalent to 5.08, 2.16 and $2.38 \mathrm{ppbv}$ ) before, during and after Hajj, respectively (Fig. 8b). But we observed a reduction up to $62 \%$ in the month of July and 


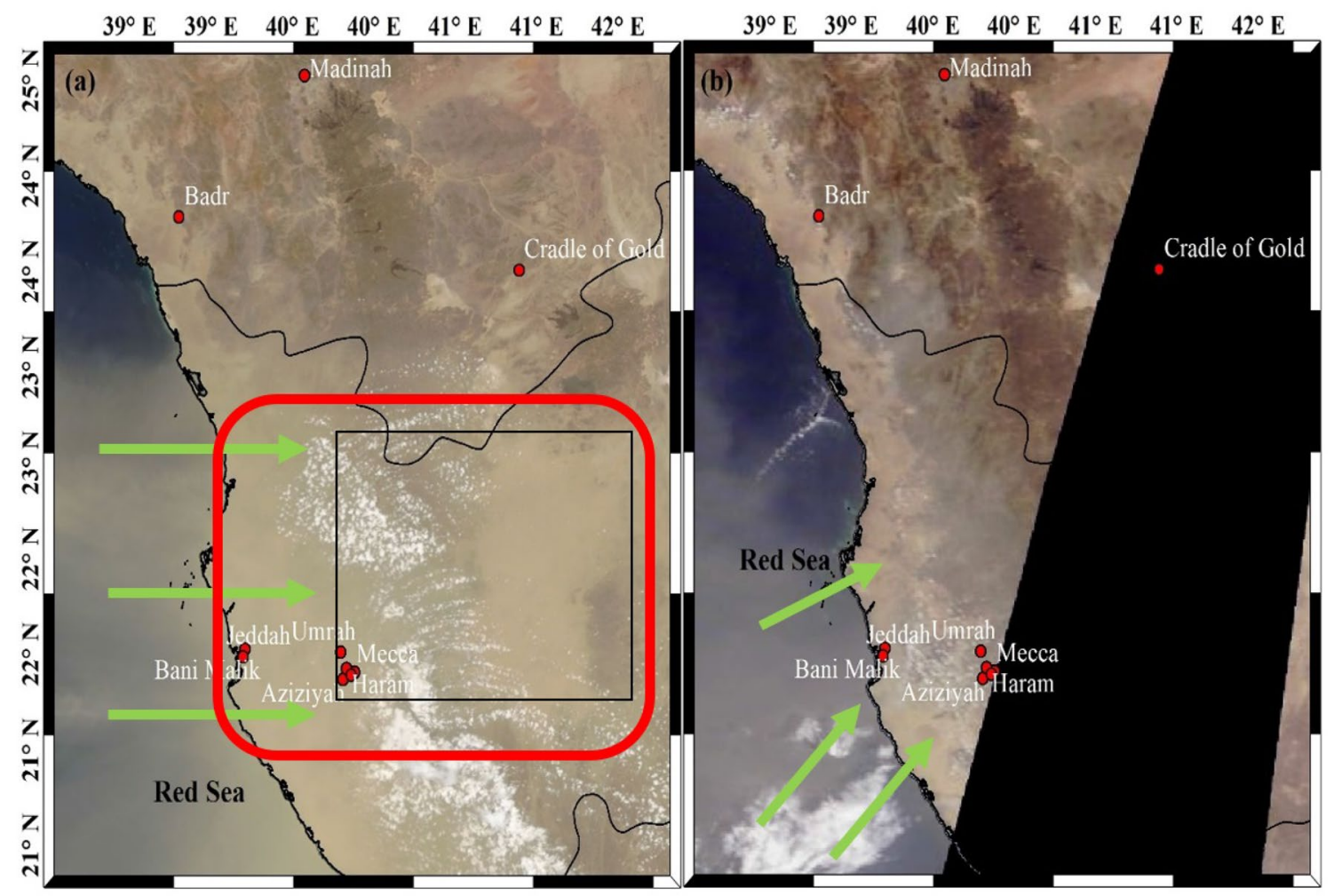

Fig. 7 Terra MODIS true colour image (RGB) (Source of image: NASA World View 2020) of Western Saudi Arabia on a 06-08-2019 and b 05-08-2020 clearly showing dust over Red sea and Mecca District. The rectangular area with red and black color show dust-covered

$77 \%$ in the month of August 2020 compared to July and August during 2019.

Near Madinah, at COD station, in 2019, the average $\mathrm{NO}_{2}$ Index is 3.78, 4.50 and 4.50 (equivalent 4.08, 4.86 and 4.86 ppbv) before, during and after Hajj, respectively. In 2020, the average $\mathrm{NO}_{2}$ Index was 1.40, 1.33 and 1.00 (equivalent to $1.51,1.44$ and $1.08 \mathrm{ppbv}$ ) before, during and after Hajj, respectively (Fig. 8c). We observed a sudden enhancement in $\mathrm{NO}_{2}$ index after the $2019 \mathrm{Hajj}$, which could be attributed to pilgrims crowds towards Madinah after the Hajj as the COD station is located in the east of the Makkah / Al- Medina highway, which was used to reach Madinah from Mecca. During 2020 Hajj, a reduction in $\mathrm{NO}_{2}$ Index up to $70 \%$ was observed at COD station compared to 2019 Hajj.

At Badr station, Madinah, only a few data points were available during the 2019 Hajj, so it was difficult to compare for two Hajj periods. At Badr station in 2019, the average $\mathrm{NO}_{2}$ Index was 7.00 and 3.00 (equivalent to 7.36 and 3.24 ppbv) during and after Hajj, respectively, and data was missing for before Hajj period. In 2020, the average $\mathrm{NO}_{2}$ Index was $2.70,1.83$ and 2.80 (equivalent to $2.9,1.9$ and $3.0 \mathrm{ppbv}$ ) before, during and after Hajj, respectively (Fig. 8d). In 2020, the average concentration was $53.6 \%$ lower at Badr station area, the green arrows show the movement of dust from the Red sea over land areas. Location of various stations are shown with red circles

with respect to 2019 . Here, we observed sudden enhancement (79.8\%) just before the Hajj and 7 days after the end of Hajj (7.2\%). An increase in traffic during Hajj, an enhancement in $\mathrm{NO}_{2}$ concentration was observed which remained within the healthy AQI limits (Fig. 9).

\subsection{Changes in CO Concentrations}

Temporal variations of CO Index are shown in (Fig. 10, Table 2) over Mecca, Jeddah, and Cradle of Gold and Badr stations near Madinah. At Mecca, in 2019, the average CO Index is $9.44,14.54$ and 12.30 [equivalent to $0.83,1.28$ and $1.08 \mathrm{ppm}$ (parts per million)] before, during and after Hajj, respectively. In 2020, the average CO Index was 8.03, 9.17 and 8.50 ( $\equiv 0.71,0.81$ and $0.75 \mathrm{ppm}$ ) before, during and after Hajj, respectively (Fig. 10a). A reduction of about $14 \%$ in CO during July and about 33\% in August 2020 was observed. In Mecca (Fig. 10a), a pronounced increase in CO index (concentration) in 2019 Hajj time and reduction of about $28 \%$ during 2020 Hajj was observed due to restrictions associated with COVID-19 (before, during and after Hajj).

In Jeddah (Fig. 10b), there are only a few data points available during the 2019 Hajj period as data was missing 


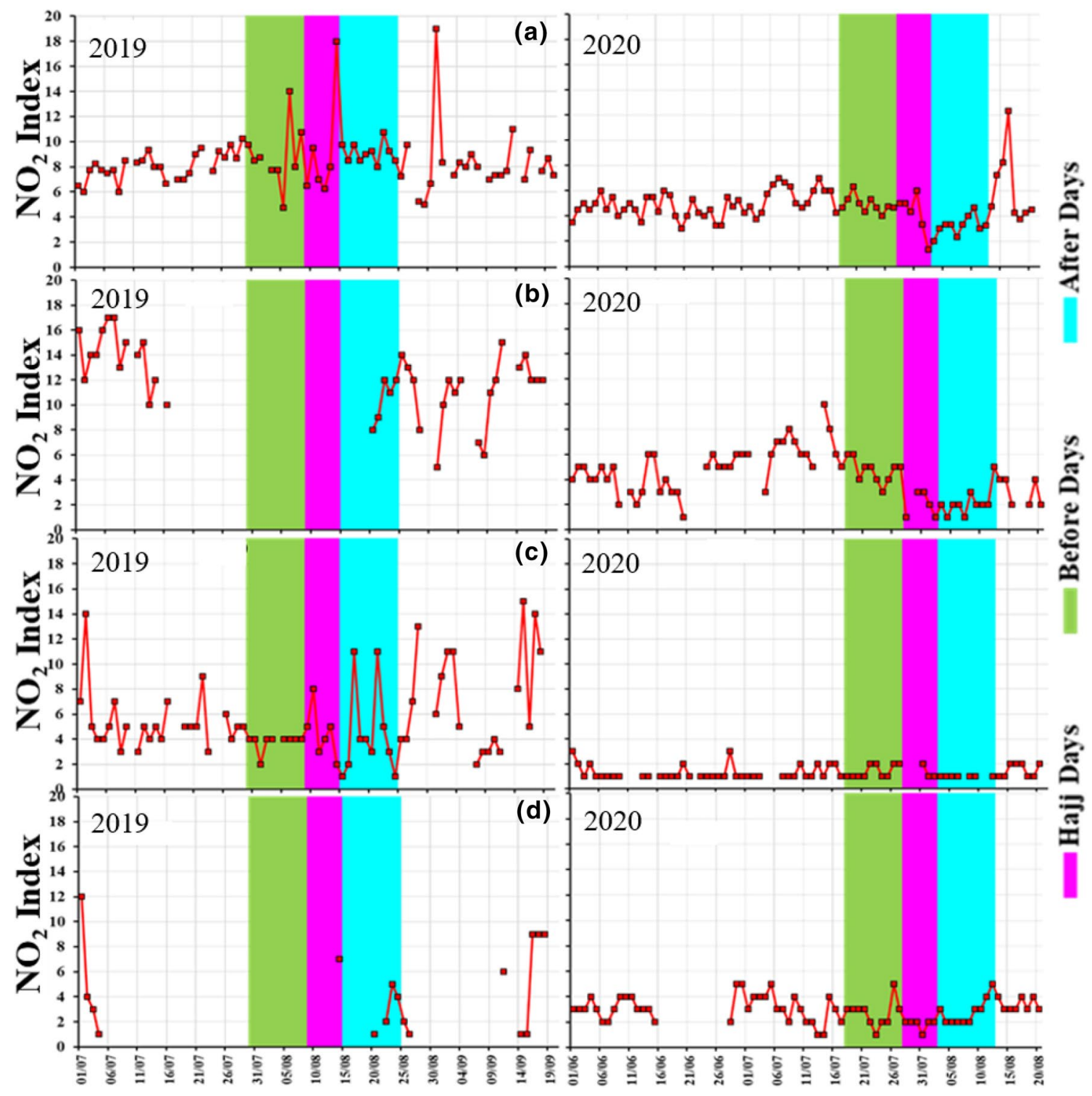

Fig. 8 Temporal Variations of surface $\mathrm{NO}_{2}$ over a Mecca, b Jeddah, $\mathbf{c}$ Cradle of Gold Station, Madinah and $\mathbf{d}$ Badr Station, Madinah during 2019 and 2020

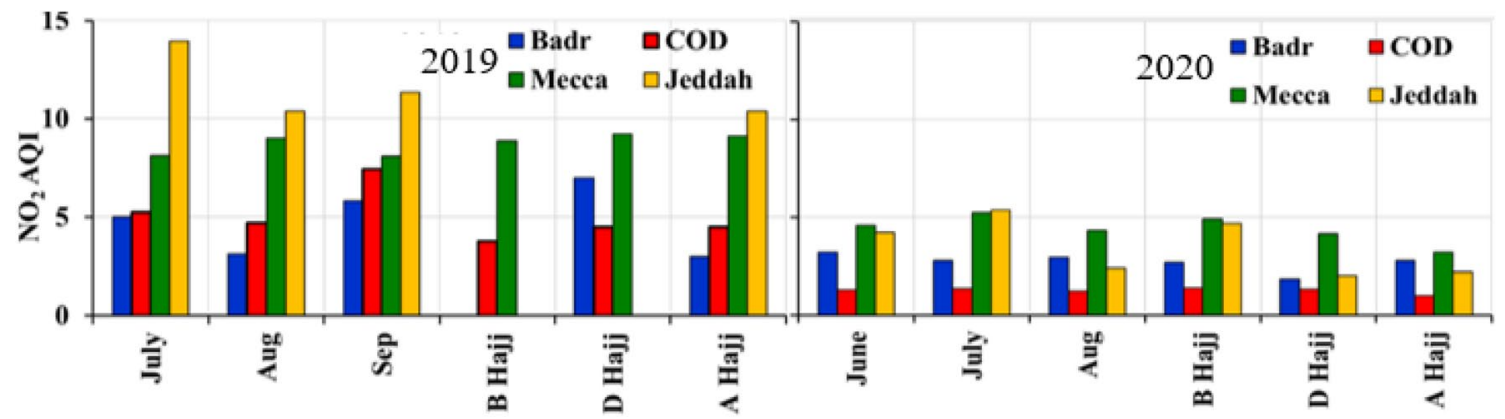

Fig. 9 Average $\mathrm{NO}_{2}$ Index over Jeddah, Badr Station Madinah, COD (Cradle of Gold) Station, Madinah, and Mecca during 2019 and 2020 . B Hajj (before Hajj); D Hajj (during Hajj) and A Hajj (after Hajj) 


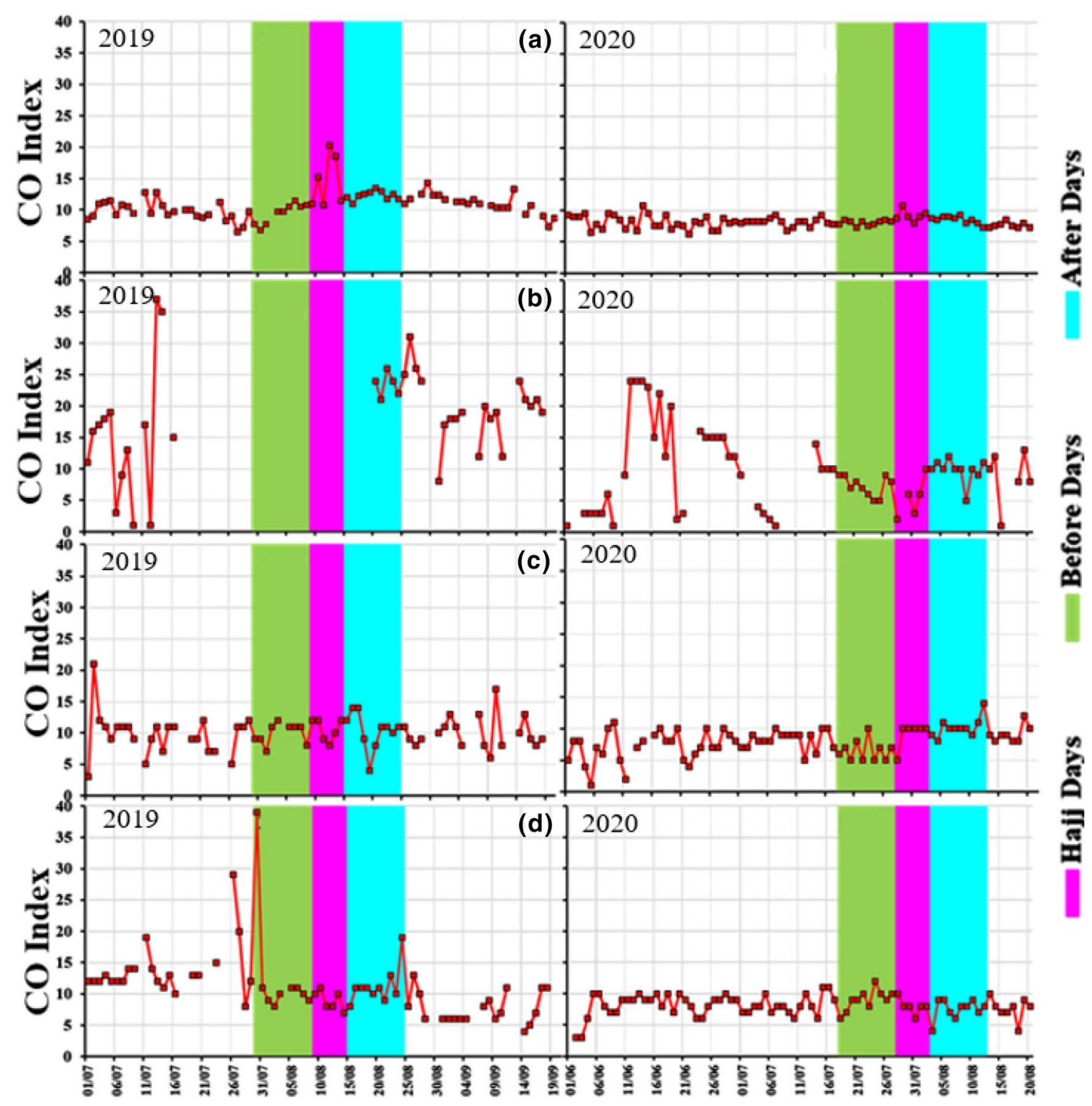

Fig. 10 Temporal Variations of surface CO Index over a Mecca, b Jeddah, c Cradle of Gold Station, Madinah and d Badr Station, Madinah during 2019 and 2020

for before and during Hajj periods. However, we observed higher CO Index values after the 2019 Hajj compared to 2020, where the average CO Index was 23.40 (equivalent to $2.06 \mathrm{ppm}$ ). The average CO Index is 7.30, 5.40 and 9.80 (equivalent to $0.64,0.48$ and $0.86 \mathrm{ppm}$ ) before, during and after 2020 Hajj, respectively (Fig. 10b).

We found a similar reduction in CO Index (concentration) at COD stations near Madinah. At COD (Fig. 10c), the average CO Index was 9.89, 10.50 and 10.40 (equivalent to 0.87 , 0.92 and $0.92 \mathrm{ppm}$ ) before, during and after Hajj 2019. The average CO Index was 6.5, 9.17 and 10.20 (equivalent to $0.57,0.81$ and $0.90 \mathrm{ppm}$ ) before, during and after 2020 Hajj, respectively. At Badr station, (Fig. 10d), the average CO
Index was $13.11,9.00$ and 11.30 (equivalent to $1.15,0.79$ and $0.99 \mathrm{ppm}$ ) before, during and after Hajj 2019. In 2020, the average CO Index was 9.00, 8.00 and 7.50 (equivalent to $0.79,0.70$ and $0.66 \mathrm{ppm}$ ) before, during and after Hajj, respectively. In 2020, we found higher in $\mathrm{CO}$ values 4 days before the Hajj and until the end of Hajj, an increase was also observed, a reduction in $\mathrm{CO}$ up to $25 \%$ during 2020 was observed compared to 2019 .

In Fig. 11, we have shown the average monthly variations of CO Index before, during and after Hajj. In 2019, the highest CO Index values were found in Jeddah, while a pronounced decrease in CO Index (concentration) during 2020 was observed compared to 2019 at all stations. In Mecca, 


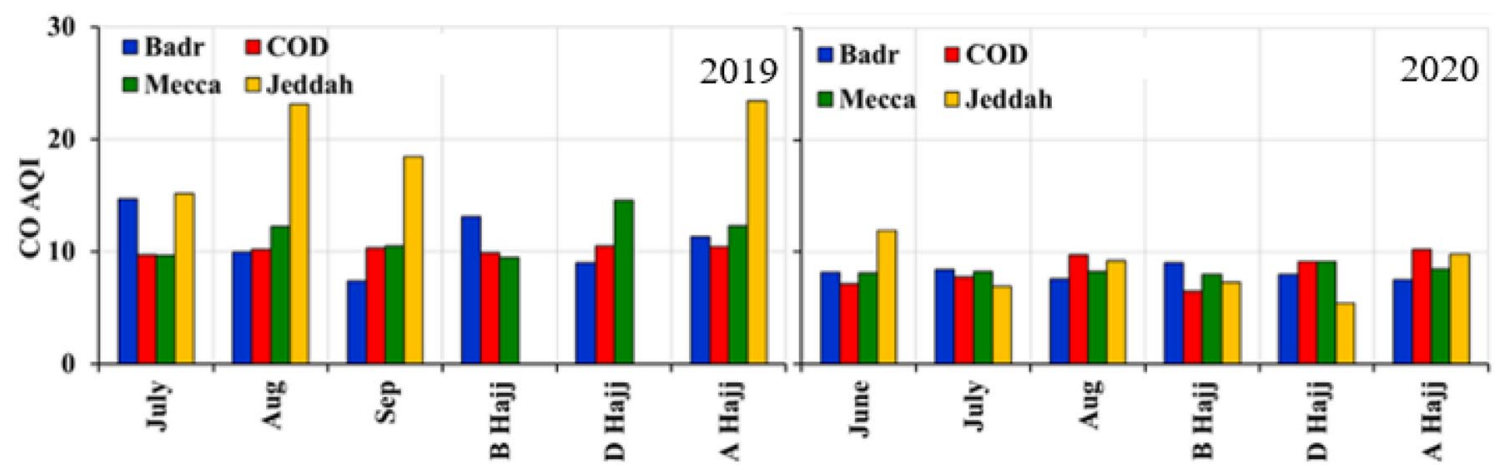

Fig. 11 Average CO Index over Jeddah, Badr Station Madinah, COD (cradle of gold) Station, Madinah, and Mecca during 2019 and 2020. B Hajj (before Hajj); D Hajj (during Hajj) and A Hajj (after Hajj)

the change in $\mathrm{CO}$ concentrations during Hajj was clearly observed during 2019 and 2020.

\section{Conclusions}

Air quality in western parts of Saudi Arabia during the Hajj period was found to be affected mainly due to the pilgrims crowds, whereas the regional climatic conditions, mainly dust storms, also influence PM concentrations at a large scale. Air quality of the cities of Mecca, Jeddah, and Madinah in Saudi Arabia is affected by the annual multimillion human gathering during the time of Hajj.

Our detailed analysis shows that the air quality of Mecca city is highly affected by Hajj activities compared to the other two cities. The pronounced changes in air quality parameters clearly show the effect of pollutants associated with the large number of vehicles transporting pilgrims to Mecca before Hajj and activities along the road from the airport to Mecca. The pollution data also clearly show a reduction in pilgrims due to strict social gathering restrictions during the $2020 \mathrm{Hajj}$. Before Hajj, $\mathrm{PM}_{10}, \mathrm{NO}_{2}$, and $\mathrm{CO}$ concentrations decreased by $54.1,44.7$, and $14.4 \%$ in 2020 compared to 2019, respectively. During $\mathrm{Hajj}, \mathrm{NO}_{2}$, and $\mathrm{CO}$ decreased by $54.7 \%$ and $36.7 \%$ respectively, while $\mathrm{PM}_{10}$ increased by $26.2 \%$. After Hajj, $\mathrm{NO}_{2}$, and $\mathrm{CO}$ decreased by $64.7,30.5 \%$, respectively, while $\mathrm{PM}_{10}$ increased by $55.6 \%$. The increase in $\mathrm{PM}_{10}$ during and after Hajj in 2020 is attributed to dust loading in the atmosphere as observed by Meteorological data.

In Jeddah, in 2019, no data were available before and during Hajj. After Hajj, 78.8, 58.2\% declination in $\mathrm{NO}_{2}$, and $\mathrm{CO}$, respectively, while a $63.4 \%$ increase in $\mathrm{PM}_{10}$ values were observed in 2020 compared to 2019. The $\mathrm{NO}_{2}$ and $\mathrm{CO}$ declination in Jeddah is another indicator of the effect of high traffic volume on anthropogenic emissions during Hajj.

On comparing 2019 and 2020, $\mathrm{NO}_{2}$ Index of various stations, we observed that $\mathrm{NO}_{2}$ Index was higher during
2019 at each station. Most of the pilgrims first arrived at Jeddah Airport and later they go to Mecca by road. Moreover, there are other anthropogenic sources in Jeddah, so the concentration was higher in Jeddah during 2019. During 2020, $\mathrm{NO}_{2}$ index values are comparable at both Mecca and Jeddah. Also, we found a higher $\mathrm{NO}_{2}$ Index during Hajj time in Mecca. Due to COVID-19 pandemic socio-economic restrictions, the anthropogenic emission was lower, overall, 2020 average values were lower compared to 2019 .

In 2020, pilgrims were restricted to visit Madinah, so it was difficult to examine the effect of Hajj on air quality of Madinah. It was, however, noticed that during 2020 Hajj there were 70.3 and $73.8 \%$ reductions in $\mathrm{NO}_{2}$ values and 11.9 and $11.3 \%$ reductions in $\mathrm{CO}$ values compared to 2019 at both COD and Badr stations near Madinah. Such reductions may not be related to Hajj activities, but it could be related to the nationwide lockdown restrictions in Saudi Arabia during summer 2020. During and after Hajj, no significant changes in $\mathrm{NO}_{2}$ or $\mathrm{CO}$ were observed at the Badr station in 2020 compared to 2019 , while a $77 \%$ declination was recorded in the COD station in 2020 compared to 2019.

Data shows that Jeddah has the highest values of $\mathrm{NO}_{2}$ and $\mathrm{CO}$ index in 2019 whereas a rapid reduction was observed in 2020. This shows that the air quality is not mainly affected by the holy gathering of the people in fact it is more due to the anthropogenic activities in the economic activity hub cities such as in Jeddah.

The results show that reducing the number of vehicles transporting pilgrims from Jeddah to Mecca and from Mecca to Madinah could help reducing air pollution during the annual Hajj season. Using environmentally friendly buses and trains to commute between the three cities could be a key solution to reduce the pollution effects. We also found that regional climatic conditions and dust storms play a significant role in $\mathrm{PM}_{10}$ variability over the Hajj cities. Even with a smaller number of pilgrims at the time Hajj, the average $\mathrm{PM}_{10}$ concentration is found to be higher in 2020 . 
Due to limited data, we are limited to show daily variations only for two years (as the data was available for 2019 and 2020). The result of 2020 will be benchmark for future study as the number of pilgrims are quite less in recent decades and these results will be helpful for future planning of Hajj in Mecca and Madinah.

\section{Data statement}

All the data used in the present study are freely available, if needed we will provide data used in the present study to anyone.

Acknowledgements Authors would like to acknowledge the support provided by the Deanship of Scientific Research (DSR) at the King Fahd University of Petroleum and Minerals (KFUPM) for funding this work through project No. DF181010. The authors are grateful to Saudi Arabia General Authority for Meteorology and Environmental Protection and the World Air Quality Index Project for providing air quality data of different locations of Saudi Arabia and to Reliable Prognosis for meteorological data. We also acknowledge the NASA team for providing the satellite true colour image. The authors thank the two anonymous referees and the Editor for their valuable comments and suggestions which have helped authors to improve the earlier version of the paper.

Author contributions Conceptualization: Ideas of this study of AF. Data analysis: AC, AF, and RS. Writing and review: AC, AF, RS, and MAO.

\section{Compliance with Ethical Standards}

Conflict of interest The authors declare that they have no known competing financial interests or personal relationships that could have appeared to influence the work reported in this paper.

Open Access This article is licensed under a Creative Commons Attribution 4.0 International License, which permits use, sharing, adaptation, distribution and reproduction in any medium or format, as long as you give appropriate credit to the original author(s) and the source, provide a link to the Creative Commons licence, and indicate if changes were made. The images or other third party material in this article are included in the article's Creative Commons licence, unless indicated otherwise in a credit line to the material. If material is not included in the article's Creative Commons licence and your intended use is not permitted by statutory regulation or exceeds the permitted use, you will need to obtain permission directly from the copyright holder. To view a copy of this licence, visit http://creativecommons.org/licenses/by/4.0/.

\section{References}

Abdel Hameed AA, Ibrahim YH, Said M, Habeeballah T, Elmorsy TH (2016) Characterization of street dust nearby the holy mosques in Ramadan and Hajj seasons, Saudi Arabia. Environ Asia 9(2)

Al Otaibi M, Farahat A, Tawabini B, Omar MH, Ramadan E, Abuelgasim A, Singh RP (2019) Long-term aerosol trends and variability over central Saudi Arabia using optical characteristics from solar village AERONET measurements. Atmosphere 10(12):752

Alam K, Trautmann T, Blaschke T, Subhan F (2014) Changes in aerosol optical properties due to dust storms in the Middle East and Southwest Asia. Remote Sens Environ 143:216-227

Al-Jeelani HA (2009) Evaluation of air quality in the Holy Makkah during Hajj season 1425 H. J Appl Sci Res 5:115-121

Ascoura IE (2013) Impact of pilgrimage (Hajj) on the urban growth of Mecca. J Educ Soc Res 3(2):255-263

Barletta B, Simpson IJ, Blake NJ, Meinardi S, Emmons LK, Aburizaiza OS, Siddique A, Zeb J, Liya EY, Khwaja HA, Farrukh MA (2017) Characterization of carbon monoxide, methane and non-methane hydrocarbons in emerging cities of Saudi Arabia and Pakistan and in Singapore. J Atmos Chem 74(1):87-113

Chauhan A, Singh RP (2020a) Decline in $\mathrm{PM}_{2.5}$ concentrations over major cities around the world associated with COVID-19. Environ Res. https://doi.org/10.1016/j.envres.2020.109634

Chauhan A, Singh RP (2020b) Effect of lockdown on HCHO and trace gases over India during March 2020. AAQR (in press)

Connerton P, Vicente de Assunção J, Maura de Miranda R, Dorothée Slovic A, José Pérez-Martínez P, Ribeiro H (2020) Air quality during COVID-19 in four megacities: lessons and challenges for public health. Int J Environ Res Public Health 17(14):5067

Corona Tracker (2020) https://www.coronatracker.com/country/saudi -arabia/. Accessed Aug 2020

Euro News (2020) https://www.euronews.com/2020/07/31/interactiv e-see-how-covid-19-has-dramatically-changed-hajj-pilgrimage). Accessed July 2020

Farahat A (2016) Air pollution in the Arabian Peninsula (Saudi Arabia, the United Arab Emirates, Kuwait, Qatar, Bahrain, and Oman): causes, effects, and aerosol categorization. Arab J Geosci 9:196. https://doi.org/10.1007/s12517-015-2203-y

Farahat A (2019) Comparative analysis of MODIS, MISR, and AERONET climatology over the Middle East and North Africa. Ann Geophys 37:49-64. https://doi.org/10.5194/angeo-37-49-2019

Farahat A, El-Askary H, Al-Shaibani A (2015) Study of aerosols' characteristics and dynamics over the Kingdom of Saudi Arabia using a multisensor approach combined with ground observations. Adv Meteorol. https://doi.org/10.1155/2015/247531

Farahat A, El-Askary H, Dogan AU (2016) Aerosols size distribution characteristics and role of precipitation during dust storm formation over Saudi Arabia. Aerosol Air Qual Res 16:2523-2534. https://doi.org/10.4209/aaqr.2015.11.0656

Hasanean H, Almazroui M (2015) Rainfall: features and variations over Saudi Arabia, a review. Climate 3(3):578-626

Howarth N, Odnoletkova N, Alshehri T, Almadani A, Lanza A, Patzek T (2020) Staying cool in a warming climate: temperature, electricity and air conditioning in Saudi Arabia. Climate $8(1): 4$

Hussain MM, Aburizaiza OS, Khwaja HA, Siddique A, Nayebare SR, Zeb J, Blake DR (2014) The state of ambient air quality of Jeddah, Saudi Arabia. AGUFM 2014:A13C-3188

Khodeir M, Shamy M, Alghamdi M, Zhong M, Sun H, Costa M, Chen LC, Maciejcczyk PM (2012) Source apportionment and elemental composition of PM2.5 and PM10 in Jeddah City, Saudi Arabia. Atmos Pollut Res 3:331-340

Kumar P, Hama S, Omidvarborna H, Sharma A, Sahani J, Abhijith KV, Debele SE, Zavala-Reyes JC, Barwise Y, Tiwari A (2020) Temporary reduction in fine particulate matter due to 'anthropogenic emissions switch-off'during COVID-19 lockdown in Indian cities. Sustain Cities Soc 62:102382

Lelieveld J, Hoor P, Jöckel P, Pozzer A, Hadjinicolaou P, Cammas JP, Beirle S (2009) Severe ozone air pollution in the Persian Gulf region. Atmos Chem Phys 9(4) 
Lim CC, Thurston GD, Shamy M, Alghamdi M, Khoder M, Mohorjy AM, Alkhalaf AK, Brocato J, Chen LC, Costa M (2018) Temporal variations of fine and coarse particulate matter sources in Jeddah, Saudi Arabia. J Air Waste Manag Assoc 68(2):123-138

Mashat AWS, Alamoudi AO, Awad AM, Assiri ME (2018) Seasonal variability and synoptic characteristics of dust cases over southwestern Saudi Arabia. Int J Climatol 38(1):105-124

MEWA (2020) Saudi Arabia general authority for meteorology and environmental protection. https://mewa.gov.sa/ar/Pages/defau lt.aspx. Accessed Nov 2020

Ministry of Hajj and Umrah (2020) https://www.haj.gov.sa. Accessed Nov 2020

Mirza AP (2020) Number of Hajj pilgrims in Saudi Arabia 1999-2019, Statista. https://www.statista.com/statistics/617696/saudi-arabi a-total-hajj-pilgrims/\#: :text=The $\% 20 \mathrm{Hajj} \% 20$ to $\% 20 \mathrm{Mecca} \% 20$ in, 2.5\%20million\%20pilgrims\%20in\%202019

Mohammed AMF, Munir S, Habeebullah TM (2015) Characterization of atmospheric aerosols in Makkah. Int J Agric Environ Res $1: 1-18$

Mohammed AMF, Habeebullah TM, Morsy EA (2016) Air pollution in Saudi Arabia - spatial variations of $\mathrm{PM}_{10}$ in Makkah (KSA). Int J Agric Environ Res 2:116-128

Munir S, Habeebullah TM, Seroji AR, Morsy EA, Mohammed AM, Saud WA, Abdou AE, Awad AH (2013) Modelling particulate matter concentrations in Makkah, applying a statistical modelingmodelling approach. Aerosol Air Qual Res 13(3):901-910

Munir S, Habeebullah TM, Mohammed AM, Morsy EA, Rehan M, Ali K (2016) Analysing PM2.5 and its association with PM10 and meteorology in the arid climate of Makkah, Saudi Arabia. Aerosol Air Qual Res 17(2):453-464

Nayebare SR, Aburizaiza OS, Siddique A, Carpenter DO, Hussain MM, Zeb J, Aburiziza AJ, Khwaja HA (2018) Ambient air quality in the holy city of Makkah: a source apportionment with elemental enrichment factors (EFs) and factor analysis (PMF). Environ Pollut 243:1791-1801

Othman N, Mat-Jafri MZ, San LH (2010) Estimating particulate matter concentration over arid region using satellite remote sensing: a case study in Makkah, Saudi Arabia. Mod Appl Sci 4:11-20

PME (2012) Presidency of Meteorology and Environment, The Royal Kingdom of Saudi Arabia. http://www.pme.gov.sa/en/en_airpo llution.asp
Rahman SM, Khondaker AN, Hasan MA, Reza I (2017) Greenhouse gas emissions from road transportation in Saudi Arabia-a challenging frontier. Renew Sustain Energy Rev 69:812-821

Seroji AR (2005) Particulates in the atmosphere of Makkah and Mina Valley during the Ramadan and Hajj seasons of 2004 and 2005. In: Brebbia CA, Longhurst JWS, Popov V (eds) Air pollution XIX. Wessex Institute of Technology, Ashurst

Siddique A (2016) Roads to Makkah: ambient air quality and personal exposure assessment during ritual of Hajj. In: Qatar foundation annual research conference proceedings, vol 2016, no 1. Hamad bin Khalifa University Press (HBKU Press), p EEPP1883

Simpson IJ, Aburizaiza OS, Siddique A, Barletta B, Blake NJ, Gartner A, Khwaja H, Meinardi S, Zeb J, Blake DR (2014) Air quality in Mecca and surrounding holy places in Saudi Arabia during Hajj: initial survey. Environ Sci Technol 48(15):8529-8537

Singh RP, Chauhan A (2020) Impact of lockdown on air quality in India during COVID-19 pandemic. Air Qual Atmos Health 13(8):921-928

SPA (2020) Saudi Press Agency. https://www.spa.gov.sa/viewfullstory. php?lang=en\&newsid=2100951. Accessed Sept 2020

Taylan O (2013) Assessing air quality in Jeddah by modeling suspended PM10 concentration. J Int Environ Appl Sci 8(3):326-335

United Nations, Department of Economic and Social Affairs, Population Division (2018) The World's Cities in 2018, Data Booklet (ST/ESA/ SER.A/417)

USEPA (2020) US Environmental Protection Agency formula. https ://www.airnow.gov/sites/default/files/2020-05/aqi-technical-assis tance-document-sept2018.pdf. Accessed Aug 2020

Vincent M (2019) Saudi Arabia sees 7,400 planes full of worshippers arrive to Mecca as around 2.5 million Muslims take part in the once in a lifetime Hajj pilgrimage, Mailonline. https://www.daily mail.co.uk/news/article-7346691/Saudi-Arabia-sees-7-400-plane s-worshippers-arrive-Mecca-2-5m-Muslims-Hajj.html

WAQIP (2020) World Air Quality Index Sitemap. https://aqicn.org/ links/. Accessed Dec 2020

Weather in the World (2020) https://rp5.ru/Weather_in_the_world. Accessed Dec 2020

World View (2020) NASA World View. https://worldview.earthdata. nasa.gov/. Accessed Dec 2020 